\title{
Association between Haplotypes and Specific Mutations in Swiss Cystic Fibrosis Families
}

\author{
SABINA LIECHTI-GALLATI, NASEEM MALIK, MUALLA ALKAN, MARCO MAECHLER, \\ MICHAEL MORRIS, FRANCINE THONNEY, FELIX SENNHAUSER, AND HANS MOSER \\ Medical Genetics Unit, Department of Pediatrics (Inselspital), University of Bern. 3010 Bern. Switzerland \\ [S.L.-G., H.M.); Dopartment of Genetics, Universitv Children's Hospital, 4058 Basel. Switzerland [N.M., M.A.]; \\ Institute of Medical Genetics, University of Zurich, 8001 Zurich, Switzerland Ma.Ma.]: Institute of Medical \\ Genetics, University of Geneva, Centre Médical Universitaire, 1211 Geneva 4, Switzerland [Mi.Mo./: Medical \\ Genetics Unit. University of Lausanne, Centre Hospitalier Universitaire Vaudois, 1011 Lausanne. Switzerland \\ [F.T.]; and Children's Hospital, St. Gallen, Switzerland [F.S.]
}

\begin{abstract}
Cystic fibrosis (CF) is the most common severe autosomal recessive genetic disorder in Caucasian populations, with an incidence of about 1 in 2000 live births, implying a carrier frequency of about 1 in 22 . In 1989, the CF gene was isolated and characterized and the major mutation $(\triangle \mathrm{F} 508)$, a 3-bp deletion that results in the loss of a phenylalanine residue at position 508 , was detected. To determine the frequency of the $\Delta$ F508 mutation and the predicted number of additional mutations in our population, we have undertaken a collaborative study of 215 CF patients and 175 CF parents in Switzerland. The $\Delta F 508$ mutation in exon 10 has been found in $70 \%$ of the CF chromosomes, and the exon-11 mutation R553X seems to be the second most common CF mutation in our population, with a frequency of $5.3 \%$, whereas the G551D mutation (also in exon 11) has not been detected at all. Haplotype determination of $430 \mathrm{CF}$ and 175 normal chromosomes using XV-2c, KM19, MP6d-9, and J3.11 has been proven to be very helpful in providing additional carrier risk calculations: Haplotypes 1 (1221), 2 (1222), 6 (2111), and 7 (2221) increase the risk of being a carrier from 1 in 55 (haplotype 6) to 1 in 17 (haplotype 1 ), whereas haplotypes 3 (1122), 4 (1112), 8 (2222) and 10 (1111) lower the risk from 1 in 144 (haplotype 3 ) to 1 in 1678 (haplotype 10). Moreover, the mutation R553X shows strong correlation with haplotype 3 , leading to the suggestion that haplotypes $1,2,5$, and 6 may account for four additional mutations in Switzerland. It is concluded that haplotype analyses should be offered to partners of individuals with a family history of $\mathrm{CF}$, giving a more informative carrier risk estimation than the global 1 in 80 . For couples at increased risks, where no completely reliable prenatal tests exist, microvillar enzyme testing in combination with DNA analysis is recommended. (Pediatr Res 30: 304-308, 1991)
\end{abstract}

Abbreviations

CF, cystic fibrosis

RFLP, restriction fragment length polymorphism PCR, polymerase chain reaction

Reccived May 10, 1990: accepted June 5, 1991

Correspondence: Dr Sabina Liechti-Gallati, Medical Genetics Unit, Department of Pediatrics (Inselspital). CH-3010 Berne. Switzerland.

Supported by the Swiss National Science Foundation, Grant No. 32-027.789, and by the CF Foundation of Switzerland (a grant to N.M.).
$\mathrm{CF}$ is the most common severe autosomal recessive genetic disorder in Caucasian populations, with an incidence of about 1 in 2000 live births, implying a carrier frequency of about 1 in 22. Its severity of expression in patients varies widely, and the disease involves multiple organ systems. Many of the symptoms of cystic fibrosis are associated with defective transport of chloride ions across epithelia, suggesting that the $\mathrm{CF}$ gene product, called the CF transmembrane conductance regulator, might be involved in the regulation or structure of the chloride channel (1). A review of the physiologic and molecular aspects of CF has recently been published (2).

One of the major breakthroughs in $\mathrm{CF}$ research was the mapping of the gene to chromosome $7 q 21-7 q 31$ by genetic linkage analysis (3-5). Subsequently, DNA sequences progressively closer to the gene were identified (6-8). DNA polymorphisms presenting allelic association with the CF gene (linkage disequilibrium) were found, implying that the majority of the $\mathrm{CF}$ chromosomes arose from one or a few mutational events (911). RFLP analysis of families that showed recombination between the markers and the disease, plus long-range restriction mapping, located the gene to a region spanning approximately $500 \mathrm{~kb}(12-15)$. In 1989, the gene was finally cloned. It is predicted to encode a protein of 1480 amino acids; the major mutation $\Delta F 508$, a 3-bp deletion that results in the loss of a phenylalanine residue at position 508 , has been defined (16-18) The frequency of $\triangle \mathrm{F} 508$ has found to be $68-78 \%$ in North American (18), British, and Dutch patients (19), whereas in Spanish and Italian populations and in black American patients the deletion is present in only $51-58 \%$ (19) and $37 \%$ (11) of the CF chromosomes, respectively. So, it seems likely there will be a large number of $\mathrm{CF}$ mutations including deletions (17), frameshift mutations (20), and point mutations (21, 22). More than 100 mutations have been detected so far, most of which are rarely found. However, two rather common CF mutations localized in exon 11 have recently been described by Cutting et al. (22): The G55ID mutation, causing an amino-acid substitution $(\mathrm{G} 1784 \rightarrow \mathrm{A}$; Gly551 $\rightarrow$ Asp), and the nonsense mutation R553X, creating a premature termination signal $(\mathrm{C} 1789 \rightarrow \mathrm{T}$; Arg553 $\rightarrow$ Stop). The ability to detect CF mutations at the DNA level offers the opportunity of more precise carrier detection and prenatal diagnosis. But effective DNA-based testing requires the definition of all CF mutations and their frequencies for individual populations because of frequency variations among different geographic locations.

We previously reported on DNA marker haplotypes of RFLP flanking the CF gene in CF families of Switzerland (23). The aim of this study was, one, to improve in our country carrier testing. prenatal diagnosis, and risk calculations by combining direct mutation analyses and haplotype information. Two, we wanted 
to contribute further information on mutation and haplotype frequencies to the CF mutation research in Europe.

To determine the $\Delta F 508$-deletion frequency and the number of additional mutations in our population, we have undertaken a collaborative study of the CF patients in Switzerland. Here, we report the results of $\Delta$ F508-, R553X-, and G551D-screening by PCR analysis and the haplotype distribution of CF and normal chromosomes that has been generated by RFLP analyses using the markers XV-2c, KM19, MP6d-9, and pJ3.11.

\section{MATERIALS AND METHODS}

Subjects. We studied $430 \mathrm{CF}$ chromosomes, from 215 patients in whom the diagnosis of CF met standard criteria (24), obtained from the five university genetic centers in Switzerland. In addition. 175 normal chromosomes from 175 parents heterozygous for $\mathrm{CF}$ have been analyzed for haplotype determination. All patients and parents are native Swiss from central, western, northern, and eastern Switzerland, mostly of Celtic and Germanic origin.

DNA analyses. DNA extraction from whole blood containing EDTA as an anticoagulant, restriction enzyme digestion, Southern blotting, and hybridization using oligo-labeled probes were performed as described before (23).

RFLP were determined for the XV-2c/TaqI, (8), KM 19/Pst I (25), MP6d-9/MspI (26), and J3.11/MspI (4) probes and haplotypes were constructed using the $\mathrm{CF}$ patients' genotypings to establish phase.

The $\Delta$ F508 deletion was detected by amplification of genomic DNA by PCR (27) followed by vertical electrophoresis in a polyacrylamide gel and ethidium bromide staining (28). The PCR primer sequences were $5^{\prime}$-GTTTTCCTGGATTATGCCTGGCAC-3' and 5'-GTTGGCATGCTTTGATGACGCTTC-3' (17).

The amplification product of the normal allele is $98 \mathrm{bp}$ and of the deleted allele is $95 \mathrm{bp}$. Two hundred pmol of each primer were used with 200-300 ng of genomic DNA and 5.0 U TaqIpolymerase (Perkin-Elmer Cetus, Kuesnacht, Switzerland) in a total volume of $100 \mu \mathrm{L}$ under paraffin oil. Annealing conditions were $64^{\circ} \mathrm{C}$ for $90 \mathrm{~s}$, extension at $72^{\circ} \mathrm{C}$ for $120 \mathrm{~s}$, and denaturation at $94^{\circ} \mathrm{C}$ for $60 \mathrm{~s}$, for 28 cycles with a final cycle of 5 min for extension in a Perkin-Elmer Amplification System. About one fifth of the amplification product was applied on a $20-\mathrm{cm} 12 \%$ polyacrylamide gel and run at $90 \mathrm{~V}$ in Tris-borate/EDTA buffer over night. Fragments were visualized and photographed after staining with ethidium bromide and illuminating them with 306 nm UV light.

The R553X mutation was detected by PCR amplification using exon-11 primers 11i-5'-CAACTGTGGTTAAAGCAATAGTGT and 11i-3'-GCACAGATTCTGAGTAACCATAAT (22), resulting in a 425-bp fragment. Hincll digestion of genomic DNA amplified from normal exon- 11 sequence produces fragments of 186 and $239 \mathrm{bp}$. The R553X as well as the G551D mutation cause the loss of the normal HincII recognition site. Normal exon-11 amplification products cannot be cut with MboI, whereas the G551D mutation creates a new Mbol-site, resulting in two fragments of 182 and $243 \mathrm{bp}$.

DNA of non- $\triangle$ F508-CF chromosomes was amplified with exon-11 primers and subsequently cut with HincII. Amplification products that showed no HincII restriction site were additionally cut with $M b o I$. PCR and gels were performed as described for $\triangle F 508$ analyses.

The mutations were confirmed by dideoxy sequencing (29) on single strand templates generated by asymmetric reamplification, using an internal primer located $3^{\prime}$ to exon 11 (Malik NJ, Hofmann S, Reiser P, Bühler EM, unpublished experiment). Asymmetric amplification was carried out using $2 \mu \mathrm{L}$ of the initial amplification products, an amplification mixture containing 1 pmol of primer $11 \mathrm{i}-5$, and $50 \mathrm{pmol}$ of primer $11 \mathrm{int}-3\left(5^{\prime}-\right.$ GTGATTCTTAACCCACTAGCC-3'). The resultant single strand DNA was purified from primers and enzyme by alcohol precipitation and one fifth of the total used for sequencing with the T7 DNA sequencing kit (Pharmacia, Dübendorf, Switzerland). Twenty pmol of the primer $11 \mathrm{i}-5$ was used as the sequencing primer.

Sequence details have generously been provided by members of the international CF genetic analysis consortium.

Risk calculations. Carrier risks for non- $\mathrm{F} 508$ chromosomes of particular haplotypes were calculated by combined statistical analysis including the Hardy-Weinberg equilibrium and the Bayes' theorem according to Lemna et al. (30) and Watson et al. (31) using the formula $R(x)=(p c / C):[p c / C+(1-p) n / N]$, where $\mathrm{p}=$ prior risk that a chromosome carries the $C F$ gene $(1 / 40)$, $\mathrm{c}=$ number of non- $\Delta \mathrm{F} 508$, non-R553X CF chromosomes carrying haplotype $\mathrm{x}, \mathrm{C}=$ total number of $\mathrm{CF}$ chromosomes (430), $\mathrm{n}=$ number of normal chromosomes with haplotype $\mathrm{x}$, and $\mathrm{N}$ $=$ number of normal chromosomes (175).

\section{RESULTS}

$\Delta$ F508-deletion. We analyzed $430 \mathrm{CF}$ chromosomes for the presence of $\triangle \mathrm{F} 508$ and found the frequency of the deletion to be $70 \%$ (301 out of 430 ). One hundred nine $(51 \%)$ of the 215 patients were found to be homozygous for the $\Delta \mathrm{F} 508$ mutation, $83(38 \%)$ were compound heterozygous, and $23(11 \%)$ did not bear the deletion on either chromosome, being either compound heterozygotes for two unknown mutations or homozygotes for one not yet defined mutation.

$R 553 X$ and $G 551 D$ mutations. The remaining $30 \%$ of $\mathrm{CF}$ chromosomes (129 out of 430) without the $\Delta \mathrm{F} 508$ mutation have been amplified with the primer pair of exon 11 followed by Hincll digestion. DNA that was not cut, demonstrating loss of the restriction site, was additionally digested by $M b o I$ to test it for G551D. After confirmation by sequencing, all of our exon 11 mutations turned out to be R553X mutations. The R553X mutation has been detected in $23(5.35 \%)$ of the $430 \mathrm{CF}$ chromosomes and in $23(18 \%)$ of the 129 non- $\Delta F 508$ chromosomes. Three patients showed homozygosity for R553X, whereas 17 were compound heterozygotes. In 14 of these 17 patients, the $\mathrm{R} 553 \mathrm{X}$ mutation was paired with the $\Delta \mathrm{F} 508$ deletion.

Haplotypes. The marker allele constellations for $\mathrm{XV}-2 \mathrm{c} /$ KM19/MP6d-9/J3.11 have been determined in 430 CF chromosomes and in 175 normal chromosomes and were expected to occur in 16 different haplotypes. The presence or absence of the $\Delta$ F508 deletion was correlated with haplotypes, and the haplotype distributions for non- $\Delta \mathrm{F} 508 \mathrm{CF}$ chromosomes as well as for normal chromosomes are presented in Figures 1 and 2 (only 11 out of 16 haplotypes have been found).

Figure 1 shows the haplotype distributions of $310 \Delta \mathrm{F} 508$ bearing $\mathrm{CF}$ chromosomes and 129 non- $\Delta \mathrm{F} 508 \mathrm{CF}$ chromosomes: $70.4 \%$ (212 out of 301 ) of the $\Delta \mathrm{F} 508$-bearing chromosomes are associated with haplotype 1 (1221);27.3\% (82 out of 301) are associated with haplotype 2 (1222); and four and three chromosomes, respectively, show haplotypes 11 (1121) (1.3\%) and 8 (2222) (1\%). The data confirm that the $\Delta \mathrm{F} 508$ deletion is strongly associated with the marker allele constellation 1221, which has previously been reported to be the most common haplotype among CF chromosomes in Caucasians $(9-11,20)$. However, the fact that the $\Delta \mathrm{F} 508$ deletion was not found on all $\mathrm{CF}$ chromosomes carrying haplotype 1 and the observation of unequal distribution of the other haplotypes suggested additional moderately common mutations correlated with particular haplotypes in our patients. The haplotype distribution of the non$\triangle F 508$ CF chromosomes is more heterogeneous: The most common haplotype is number 3 (1122), detected in $25(19.4 \%)$ of the $129 \mathrm{CF}$ chromosomes without the $\triangle \mathrm{F} 508$ mutation and strongly linked to the exon-11 mutation R553X. Every R553Xbearing chromosome had the haplotype 3 , and, conversely, all but two haplotype 3 chromosomes showed the R553X mutation. Haplotypes 1 (21 out of 129) and $2(17$ out of 129) as well as 5 


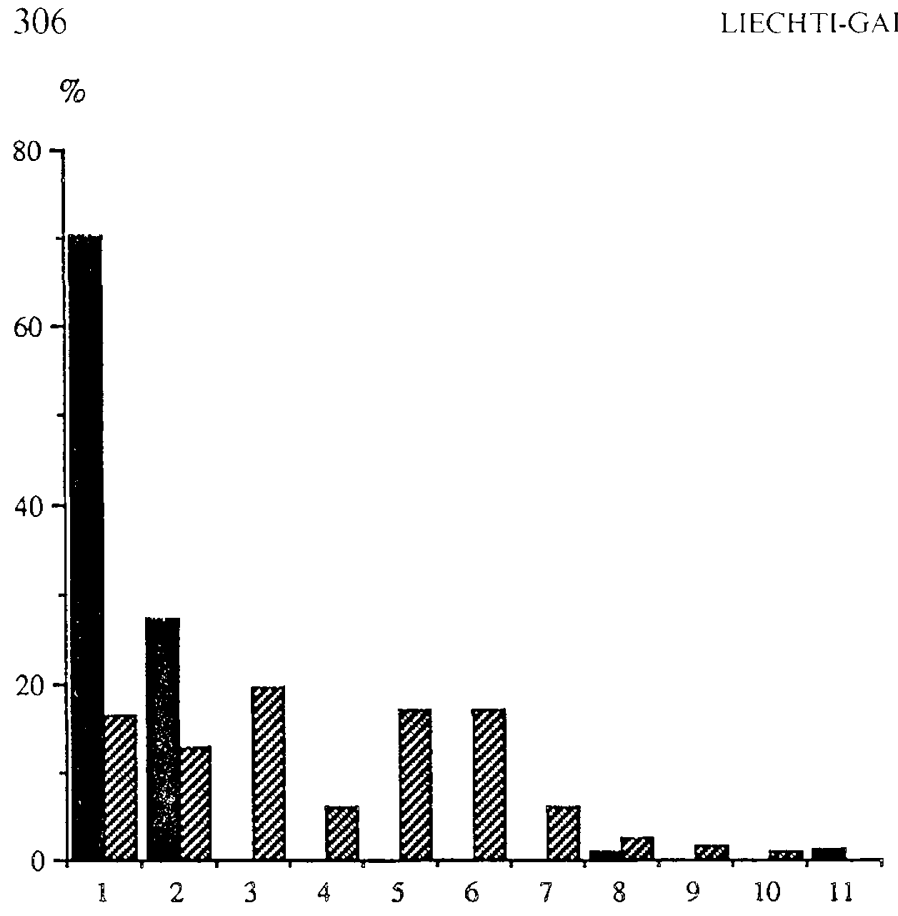

Fig. 1. Haplotype distributions of 301$\lrcorner$ F508 chromosomes $(\boldsymbol{\square})$ and 129 non- $\mathrm{F} 508 \mathrm{CF}$ chromosomes (\$). 1-11, haplotypes generated from allele constellations of the markers XV-2c/KM19/MP6d-9/J3.11. 1 . 1221: 2, 1222:3, 1122 (correlated with R553X): 4, 1112; 5, 2112:6. $2111: 7,2221: 8.2222: 9,2122 ; 10,1111: 11,1121$

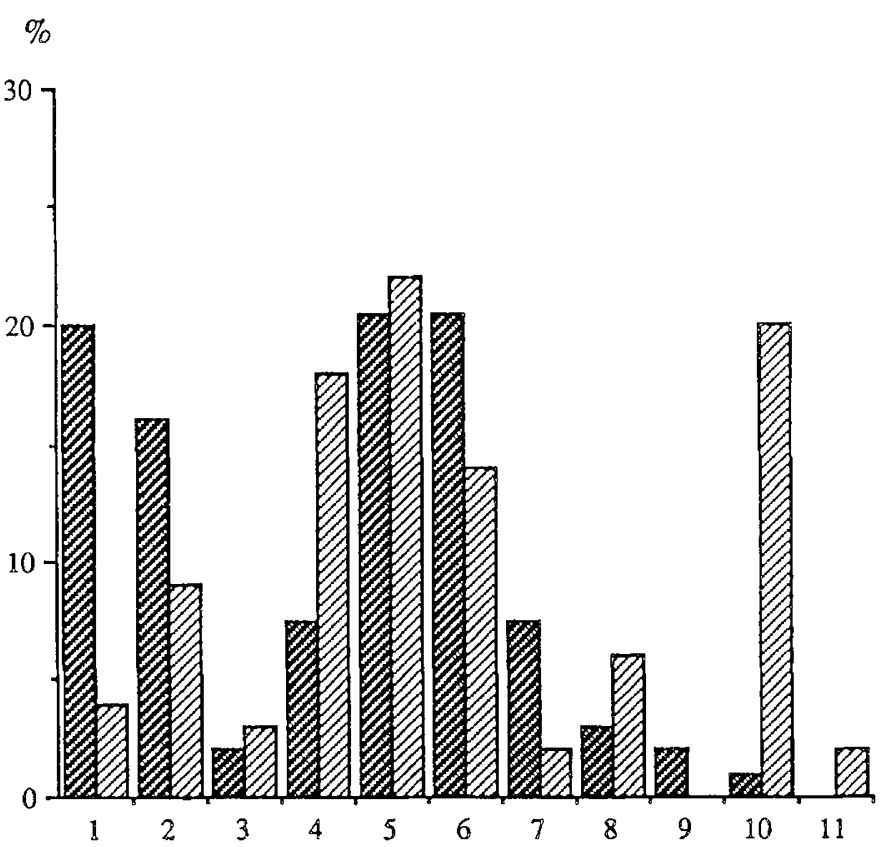

Fig. 2. Haplotype distributions of 106 non- $\mathrm{F} 508$, non-R553X CF chromosomes $(\mathbb{S})$ and 175 normal chromosomes $(\mathbb{Q})$. 1-11, haplotypes generated from allele constellations of the markers XV-2c/KM19/MP6d-

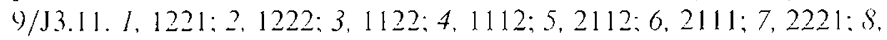
$2222 ; 9,2122 ; 10,1111 ; 11.1121$.

(22 out of 129) and 6 (22 out of 129) are also rather frequent, occurring in $13-17 \%$ of non- $\triangle \mathrm{F} 508$ chromosomes; they may be specifically correlated with four additional mutations. Haplotypes 4 and 7 are present in eight of 128 non- $\Delta$ F508 CF chromosomes each, whereas haplotypes 8 (three out of 129), 9 (two out of 129), and 10 (one out of 129) are rarely found.

Figure 2 demonstrates the haplotype distributions of normal chromosomes versus $\mathrm{CF}$ chromosomes without the $\Delta \mathrm{F} 508$ deletion and without the R553X mutation. Normal chromosomes seem to be preferably associated with haplotypes 5 (38 out of $175 ; 22 \%), 10$ ( 35 out oi $175 ; 20 \%), 4(31$ out of $175 ; 18 \%)$, and $6(25$ out of $175 ; 14 \%)$, whereas haplotypes 2 (15 out of 175 ; $9 \%), 8(10$ out of $175 ; 6 \%), 1$ (seven out of $175 ; 4 \%$ ), and 3 (six out of $175 ; 3 \%)$ are represented in lower frequencies and haplotypes 7 and 11 are rarely found (four out of $175 ; 2 \%$ ). Moreover, haplotypes 12-16 (1211/1212/2121/2212/2211) have not been detected at all, either in CF or in normal chromosomes. When comparing the haplotype frequencies of normal and non- $\Delta \mathrm{F} 508$, non-R553X chromosomes, haplotypes $10,4,3$, and 8 indicate a normal chromosome with a very high probability. In contrast, the risk of carrying a CF mutation is obviously increased in the presence of haplotypes $1,2,6$, and 7 .

Table 1 shows the risks for non- $\Delta \mathrm{F} 508$, non-R553X chromosomes of specific haplotypes to be CF chromosomes and the carrier risk calculations for individuals of specific non- $\Delta F 508$, non-R553X genotypes.

\section{DISCUSSION}

Previous results provided by the original North American study (18) and data reported by other groups (19) indicated that the $\Delta \mathrm{F} 508$ deletion is present in more than two thirds of $\mathrm{CF}$ chromosomes in Northern Europe. We have analyzed 215 patients from Switzerland and found the $\Delta \mathrm{F} 508$ frequency to be $70 \%$. This finding supports the hypothesis that the predominant CF mutation, present throughout Europe, originated in a specific location before spreading according to a northwest-southeast gradient to all populations by migration $(19,32)$.

Examination of exon 11 revealed only one of the four mutations described by Cutting et al. (22), R553X. This nonsense mutation was found on 23 of 129 non- $\Delta F 508$ CF chromosomes, resulting in a frequency of $18 \%$. It therefore seems to be the second most common CF mutation in our population. Cutting et al. (22) reported the G551D mutation (which we did not detect at all) to be found in $4 \%$ of CF chromosomes of Caucasian and the R553X mutation to be found in $5 \%$ of CF chromosomes of black Americans. Provisional data from different European countries show $0.5-13 \%$ of the non- $\Delta \mathrm{F} 508 \mathrm{CF}$ chromosomes carrying the G551D mutation and $1-10 \%$ of the non- $\Delta$ F508 CF

Table 1. Risks for non- $\Delta F 508$, non-R553X chromosomes to be $C F$-chromosomes and carrier risks for individuals of specific non- $\Delta F 508$, non- $R 553 X$ genotypes

\begin{tabular}{cccccc}
\hline $\begin{array}{c}\text { Haplo- } \\
\text { type }\end{array}$ & Risk & $\begin{array}{c}\text { Geno- } \\
\text { type }\end{array}$ & $\begin{array}{c}\text { Carrier } \\
\text { risk }\end{array}$ & $\begin{array}{c}\text { Geno- } \\
\text { type }\end{array}$ & $\begin{array}{c}\text { Carrier } \\
\text { risk }\end{array}$ \\
\hline & & $1 / 1$ & 1 in 17 & $3 / 10$ & 1 in 265 \\
1 & 1 in 33 & $1 / 2$ & 1 in 24 & $4 / 4$ & 1 in 186 \\
2 & 1 in 86 & $1 / 3$ & 1 in 29 & $4 / 5$ & 1 in 115 \\
3 & 1 in 288 & $1 / 4$ & 1 in 30 & $4 / 6$ & 1 in 85 \\
4 & 1 in 372 & $1 / 5$ & 1 in 27 & $4 / 7$ & 1 in 43 \\
5 & 1 in 167 & $1 / 6$ & 1 in 25 & $4 / 8$ & 1 in 172 \\
6 & 1 in 110 & $1 / 7$ & 1 in 20 & $4 / 10$ & 1 in 335 \\
7 & 1 in 49 & $1 / 8$ & 1 in 30 & $5 / 5$ & 1 in 83 \\
8 & 1 in 320 & $1 / 10$ & 1 in 33 & $5 / 6$ & 1 in 66 \\
10 & 1 in 3357 & $2 / 2$ & 1 in 43 & $5 / 7$ & 1 in 38 \\
& & $2 / 3$ & 1 in 66 & $5 / 8$ & 1 in 110 \\
& & $2 / 4$ & 1 in 70 & $5 / 10$ & 1 in 159 \\
& & $2 / 5$ & 1 in 57 & $6 / 6$ & 1 in 55 \\
& & $2 / 6$ & 1 in 48 & $6 / 7$ & 1 in 34 \\
& & $2 / 7$ & 1 in 31 & $6 / 8$ & 1 in 82 \\
& & $2 / 8$ & 1 in 68 & $6 / 10$ & 1 in 106 \\
& & $2 / 10$ & 1 in 84 & $7 / 7$ & 1 in 25 \\
& & $3 / 3$ & 1 in 144 & $7 / 8$ & 1 in 42 \\
& & $3 / 4$ & 1 in 162 & $7 / 10$ & 1 in 48 \\
& & $3 / 5$ & 1 in 106 & $8 / 8$ & 1 in 160 \\
& & $3 / 6$ & 1 in 80 & $8 / 10$ & 1 in 292 \\
& & $3 / 7$ & 1 in 42 & $10 / 10$ & 1 in 1678 \\
\hline & $3 / 8$ & 1 in 152 & & \\
\hline
\end{tabular}


chromosomes carrying the R553X mutation (personal communication from the European Community Cystic Fibrosis Consortium).

Identification of the $\Delta \mathrm{F} 508$ and R553X mutations allow the detection of $75 \%$ of CF chromosomes in Switzerland, raising the question of population-based screening for carriers. The detection of multiple individually rare mutations (more than 100 at the time of writing) makes carrier testing more and more difficult, and, if no more than $95 \%$ of carriers can be detected, screening may not be advisable $(33,34)$. However, carrier testing that is nearly $100 \%$ informative can be offered to all individuals with a family history of $C F$, inasmuch as carrier detection can be performed by linkage analyses in addition to mutation analyses.

The association between DNA polymorphism haplotypes and specific gene mutations has been proven to be of great value in a variety of autosomal recessive disorders. Therefore, we determined the haplotypes of $301 \Delta \mathrm{F} 508$ and 129 non- $\triangle F 508$ CF chromosomes and 175 normal chromosomes using three DNA markers (XV-2c, KM19, MP6d-9) centromeric and one marker (J3.11) telomeric to the CF gene. The $\Delta$ F508 deletion was almost exclusively associated with haplotypes $1(70.5 \%)$ and $2(27 \%)$, which have previously been found to occur most commonly in $\mathrm{CF}$ chromosomes $(10,11,23)$. Haplotype frequencies of the non$\triangle F 508$ CF chromosomes may differ from country to country depending on ethnic background, for example racial admixture, and on the location and the moment when a new mutation occurred. The strong correlation of the R533X mutation with haplotype 3 suggests that haplotypes $1,2,5$, and 6 may be associated with at least four other specific mutations. As long as these mutations are not known, haplotype frequencies can be used for carrier risk calculations.

Screening for $\Delta \mathrm{F} 508$ and R553X detects the mutation in $75 \%$ of CF chromosomes in Switzerland. If a non-related partner of an individual heterozygous for CF tests negative for $\Delta F 508$ and $\mathrm{R} 553 \mathrm{X}$, his risk of being a carrier decreases from the population risk of 1 in 20 down to 1 in 80 . Combination with haplotype data provides still more accurate calculations: Table 1 shows the risk that a non- $\Delta \mathrm{F} 508$, non-R553X chromosome of a particular haplotype is a CF chromosome and the carrier risks for individuals of specific non- $\Delta$ F508, non-R553X genotypes. The data demonstrate that haplotypes generated from the marker allele constellation of XV-2c, KM19, MP6d-9, and J3.11 influence strongly carrier risk calculations. Haplotypes 1, 2, 6, and 7 increase the risk of being a carrier from 1 in 55 (haplotype 6) to 1 in 17 (haplotype 1), whereas haplotypes 3, 4, 8, and 10 lower the risk from 1 in 144 (haplotype 3) to 1 in 1678 (haplotype 10). However, the global risk of 1 in 80 is not markedly changed by haplotype 5, inasmuch as it shows approximately the same frequency in normal and non- $\Delta \mathrm{F} 508$ chromosomes. Mutations on chromosomes carrying haplotype 5 may be of more recent origin. Thus, haplotype analyses that give a more informative risk estimation than the global 1 in 80 should be offered to partners of individuals with a family history of CF. Where one partner is a known carrier and the other has genotype $4 / 4$, the risk in any pregnancy decreases from 1 in 320 to 1 in 744 , whereas for genotype $1 / 1$ the risk increases to 1 in 68 . For couples at increased risk, there are no completely reliable prenatal tests; however, microvillar enzyme testing in combination with DNA analysis is recommended in this situation and will provide the most help possible to the couple in deciding whether they want the pregnancy to be interrupted or continued.

On the basis of PCR analyses for $\triangle F 508$ and R553X in conjunction with DNA marker haplotype comparisons, we conclude that there are at least four additional CF mutations in our population. Three of our CF patients have been found to be homozygous for R553X; they present with normal weight and low Crispin Norman scores up to the age of 10 and rapid progression from the age of 12 , suggesting a two-stage course. Further studies on clinical symptoms in correlation with haplo- types are under investigation, and we hope to determine precisely what the additional CF mutations are in our population.

Acknowledgments. The authors thank Prof. R. Williamson, Dr. X. Estivill, and Prof. J. Schmidtke for providing us with the probes XV-2c, KM 19, MP6d-9, and J3.11. We are indebted to Dr. Robin Winter, Northwick Park Hospital, Harrow, Middlesex, for his helpful assistance in performing the carrier risk calculations.

\section{REFERENCES}

1. Ringe D, Petsko GA 1990 Cystic fibrosis-a transport problem? Nature 346:312-313

2. Krauss RD, Rado TA 1989 Review: current approaches to the molecular and physiological basis of cystic fibrosis. Am J Med Sci 298:334-341

3. Tsui LC, Buchwald M. Barker D. Braman JC, Knowlton RG, Schumm JW, Eiberg H, Mohr J, Kennedy D, Plavsic N. Zsiga M. Markiewicz D. Akoto G. Brown V. Helms C. Granvins T, Parker C, Rediker K. Donis-Keller H 1985 Cystic fibrosis locus defined by a genetically linked polymorphic DNA marker. Science 230:1054-1057

4. Wainwright BJ. Scambler PJ, Schmidtke J, Watson EA, Law HJ, Farrall M, Cooke HJ, Eiberg H, Williamson R 1985 Localization of cystic fibrosis locus to human chromosome 7cen-q22. Nature 318:384-385

5 White R, Woodward S, Leppert M O'Connell P. Nakamura Y. Hoff M. Herbst J. Lalouel JM. Dean M. Vande Woude G 1985 A closely linked genetic marker for cystic fibrosis. Nature 318:382-384

6. Zengerling S. Olek K. Tsui LC. Grzeschik KH. Riordan JR. Buchwald M 1987 Mapping of DNA markers linked to the cystic fibrosis locus on the long arm of chromosome 7. Am J Hum Genet 40:228-236

7. Collins FS, Drumm ML. Cole JL, Lockwood WK. Vande Woude GF. Lannuzzi MC 1987 Construction of a general human chromosome jumping library with application to cystic fibrosis. Science 235:1046-1049

8. Estivill X, Farrall M, Scambler JP. Bell GM, Hawley KMF, Bates GP. Kruyer HC, Frederick PA, Stanier P. Watson EK. Williamson R, Wainwright BJ 1987 A candidate for the cystic fibrosis locus isolated by selection for methylation-frec islands. Nature 326:840-845

9. Estivill X. Farrall M. Williamson R. Ferrari M, Seia M. Giunta AM, Novelli G, Potenza L. Dallapicolla B. Borgo G, Gasparini P. Pignatti PF, De Benedetti L Vitale E, Devoto M. Romeo G 1988 Linkage disequilibrium between cystic fibrosis and linked DNA polymorphisms in Italian families: a collaborative study. Am J Hum Genet 43:23-28

10. Beaudet A. Feldman G. Fernbach S, Buffone G. O’Brien W 1989 Linkage disequilibrium. cystic fibrosis, and genetic counseling. Am J Hum Genct 44:319-329

11. Cutting G. Antonarakis S, Buetow K. Kasch L, Rosenstein B, Kazazian H 1989 Analysis of DNA polymorphism haplotypes linked to the cystic fibrosis locus in North American black and Caucasian families supports the existence of multiple mutations of the cystic fibrosis gene. Am J Hum Genet 44:307318

12. Drumm M. Smith C. Dean M. Cole J. Iannuzzi M. Collins F 1988 Physical mapping of the cystic fibrosis region by pulse-field gel electrophoresis. Genomics 2:346-354

13. Poustka A, Lehrach H. Williamson R. Bates G 1988 A long-range restriction map encompassing the cystic fibrosis locus and its closely linked genetic markers. Genomics 2:337-345

14. Iannuzzi MC. Dean M. Drumm ML, Hidaka N, Cole JL. Perry A. Stewart C, Gerrard B. Collins F 1989 Isolation of additional polymorphic clones from the cystic tibrosis region. using chromosome jumping from D7S8. Am J Hum Genet 44:695-703

15. Dean M. Drumm ML, Stewart C. Gerrard B, Perry A. Kidaka N, Cole JL. Collins F, Iannuzzi MC 1989 Approaches to localizing discase genes as applied to cystic fibrosis. Nucleic Acids Res 18:345-350

16. Rommens JM. Iannuzzi MC. Kerem BS. Drumm ML Melmer G, Dean M. Rozmahel R, Cole JL. Kennedy D. Hidaka N, Zsiga M. Buchwald M. Riordan JR. Tsui LC. Collins FS 1989 Identification of the cystic fibrosis gcne: chromosome walking and jumping. Scicnce 245:1059-1065

17. Riordan JR. Rommens JM, kerem BS, Alon N. Rozmahel R. Grzelczak Z. Zielensi J, Lok S. Plavsic N. Chou JL. Drumm ML. Jannuzzi MC. Collins FS, Tsui LC 1989 Identification of the cystic fibrosis gene: cloning and characterization of complementary DNA. Science 245:1066-1072

18. Kerem BS, Rommens JM, Buchanan JA. Markiewicz D. Cox TK, Chakravarti A, Buchwald M. Tsui LC 1989 Identification of the cystic fibrosis gene: genetic analysis. Science 245:1073-1080

19. Romeo G. Devoto M 1990 Population analysis of the major mutation in cystic fibrosis. Hum Genet 85:391-445

20. White M, Amos J. Hsu JMC, Gerrard B. Finn P, Dean M 1990 A frameshift mutation in the cystic fibrosis gene. Nature 344:665-667

21. Dean M, White MB, Amos J, Gerrard B. Stewart C, Khaw KT, Leppert M 1990 Multiple mutations in highly conserved residucs are found in mildly affected cystic fibrosis paticnts. Cell 61:863-870

22. Cutting GR, Kasch LM, Rosenstcin BJ Zielenski J. Tsui LC. Antonarakis SE. Kazazian HH 1990 A cluster of cystic fibrosis mutations in the first nucieotide-binding fold of the cystic fibrosis conductance regulator protein. Nature 346:366-369 
23. Liechti-Gallati S, Niederer BU, Schneider V, Mächler M, Alkan M, Malik N, Braga S, Moser H 1990 Haplotype analysis for CF-linked DNA polymorphisms in Switzerland. Clin Genet 37:442 -449

24. Boat TF, Welsh MJ, Beaudet AL 1989 Cystic fibrosis. In: Scriver CR, Beaudet AL. Sly WS. Valle D (eds) The Metabolic Basis of Inherited Disease, 6th Ed. McGraw-Hill, New York, pp 2649-2680

25. Estivill X. Scambler PJ, Wainwright BJ, Hawley K, Frederick P, Schwartz M, Baiget M, Kere J, Williamson R, Farrall M 1987 Patterns of polymorphisms and linkage disequilibrium for cystic fibrosis. Genomics 1:257-263

26. Estivill X, McLean C, Nunes V, Casals T, Gallano P, Scambler PJ, Williamson $\mathrm{R} 1989$ Isolation of new DNA marker in linkage disequilibrium with cystic fibrosis, situated between J3.11 (D7S8) and IRP. Am J Hum Genet 44:704710

27. Saiki RK. Gelfand DH, Stoffel S, Scharf SJ, Higuchi R, Horn GT, Mullis KB 1988 Primer-directed enzymatic amplification of DNA with thermostable DNA polymerase. Science 239:487-491
28. Mathew CG, Roberts RG, Harris A, Bentley DR, Bobrow M 1989 Rapid screening for $\triangle \mathrm{F} 508$ deletion in cystic fibrosis. Lancet 2:1346

29. Sanger F, Nicklen S, Coulson AR 1977 DNA sequencing with chain-terminating inhibitors. Proc Natl Sci USA 74:5463-5467

30. Lemna WK. Feldman GL, Kerem BS, Fernbach SD, Zevkovich EP, O'Brien WE, Riordan JR. Collins FS, Tsui LC, Beaudet AL 1990 Mutation analysis for heterozygote detection and the prenatal diagnosis of cystic fibrosis. $N$ Engl J Med 322:291-296

31. Watson E, Williamson R, Brueton B, Winter R 1990 Genetic counselling for cystic fibrosis based upon mutation/haplotype analysis. Lancet 2:190-191

32. Serre JL, Simon-Bouy B, Mornet E, Jaume-Roig B, Balassopoulou A, Schwart M, Taillandier A, Boué J. Boué A 1990 Studies of RFLP closely linked to the cystic fibrosis locus throughout Europe lead to new considerations in populations genetics. Hum Genet 84:449-454

33. Ten Kate LP, Tijmstra TJ 1989 Carrier screening for cystic fibrosis. Lancet 2:973-974

34. Colten HR 1990 Screening for cystic fibrosis: public policy and personal choices. N Engl J Med 322:328-329 